\title{
PEMENUHAN MAKANAN BALITA DI DESA RANAH SINGKUANG KABUPATEN KAMPAR
}

\author{
Syukrianti Syahda ${ }^{1}$, Ria Irena $^{2}$ \\ ${ }^{1,2,)}$ Program Studi DIV Kebidanan, Fakultas Ilmu Kesehatan, Universitas Pahlawan Tuanku Tambusai \\ e-mail: syukrianti@gmail.com
}

\begin{abstract}
Abstrak
Gizi kurang sering dialami oleh balita, salah satu faktor yang berpengaruh terhadap masalah gizi kurang ini adalah masih rendahnya pengetahuan masyarakat tentang pemeliharaan gizi balita, sehingga berdampak pada kurangya konsumsi zat gizi anak. Konsumsi zat gizi yang kurang pada balita dapat berakibat terganggunya pertumbuhan dan perkembangan anak serta melemahnya daya tahan tubuh terhadap infeksi. Keadaan ini akan memperburuk status gizi anak. PKM ini diusulkan karena mencermati masih banyaknya jumlah balita dengan gizi kurang dan stanting di Desa Ranah Singkuang wilayah kerja Puskesmas Kampar yang merupakan potret kecil dari masyarakat Indonesia. Setiap kelompok kader posyandu selalu aktif dan bertugas menyiapkan makanan tambahan untuk balita yang datang sekaligus memberikan contoh menu sehat untuk pengunjung posyandu. Namun, berdasarkan informasi dari koordinator kader, makanan yang disiapkan cenderung monoton tanpa variasi yang menarik dan tanpa memperhatikan perbedaan kebutuhan balita tersebut. Menu MP-ASI dan PMT balita yang disajikan antara lain bubur kacang hijau, sesekali diberi bubur ayam. Hal ini disebabkan menu yang disajikan sesuai dengan sumber dari Puskesmas setempat yang harus ditunggu karena kendala ekonomi masyarakat setempat.
\end{abstract}

Kata kunci: Pemenuhan Makanan Balita, Penyuluhan, Pelatihan

\begin{abstract}
Undernutrition is often experienced by toddlers, one of the factors that influence the problem of undernutrition is the low level of public knowledge about nutrition maintenance for toddlers, so that it has an impact on the lack of consumption of children's nutrients. Consumption of less nutrients in children under five can result in impaired growth and development of children as well as weakening the body's resistance to infection. This situation will worsen the nutritional status of children. This PKM was proposed because it observes the large number of children under five with malnutrition and stunting in Ranah Singkuang Village, the working area of the Kampar Health Center, which is a small portrait of the Indonesian people. Each group of posyandu cadres is always active and in charge of preparing additional food for toddlers who come as well as providing examples of healthy menus for posyandu visitors. However, based on information from the cadre coordinator, the food prepared tends to be monotonous without interesting variations and without paying attention to the different needs of the toddlers. The menu for MP-ASI and PMT for toddlers includes green bean porridge, occasionally given chicken porridge. This is because the menu served is in accordance with the source from the local health center which must be waited for due to the economic constraints of the local community.
\end{abstract}

Keywords: Fulfillment of toddler food, counseling, training

\section{PENDAHULUAN}

Kebutuhan gizi merupakan kebutuhan yang sangat penting dalam membantu proses pertumbuhan dan perkembangan pada anak. Pemenuhan gizi yang sesuai dengan kebutuhan akan mendorong pertumbuhan yang baik dan sesuai dengan tahap perkembangannya sehingga dapat membentuk generasi yang sehat, cerdas, dan produktif. Sebaliknya, jika kebutuhan gizi dalam tubuh tidak tercukupi maka akan mengakibatkan berbagai masalah gizi seperti gizi kurang, gizi lebih, defisiensi zat besi, dan zink.

Gizi kurang sering dialami oleh balita, salah satu faktor yang berpengaruh terhadap masalah gizi kurang ini adalah masih rendahnya pengetahuan masyarakat tentang pemeliharaan gizi balita, sehingga berdampak pada kurangya konsumsi zat gizi anak. Konsumsi zat gizi yang kurang pada 
balita dapat berakibat terganggunya pertumbuhan dan perkembangan anak serta melemahnya daya tahan tubuh terhadap infeksi. Keadaan ini akan memperburuk status gizi anak.

Selama ini, pemerintah sudah melakukan upaya untuk memperbaiki status gizi anak balita terutama gizi kurang dengan program pemenuhan makanan, baik makanan pendamping ASI (MPASI) maupun pemenuhan makanan tambahan (PMT) balita. Pemberian tersebut dalam bentuk biskuit untuk MP-ASI dan bubur kacang hijau untuk PMT balita yang pemberiannya dikoordinasi oleh tenaga gizi puskesmas, bidan pustu, dan kader posyandu setempat untuk balita sasaran.

PKM ini diusulkan karena mencermati masih banyaknya jumlah balita dengan gizi kurang dan stanting di Desa Ranah Singkuang wilayah kerja Puskesmas Kampar yang merupakan potret kecil dari masyarakat Indonesia. Setiap kelompok kader posyandu selalu aktif dan bertugas menyiapkan makanan tambahan untuk balita yang datang sekaligus memberikan contoh menu sehat untuk pengunjung posyandu. Namun, berdasarkan informasi dari koordinator kader, makanan yang disiapkan cenderung monoton tanpa variasi yang menarik dan tanpa memperhatikan perbedaan kebutuhan balita tersebut. Menu MP-ASI dan PMT balita yang disajikan antara lain bubur kacang hijau, sesekali diberi bubur ayam. Hal ini disebabkan menu yang disajikan sesuai dengan sumber dari Puskesmas setempat yang harus ditunggu karena kendala ekonomi masyarakat setempat.

Padahal, para kader seharusnya kreatif dan inovatif dengan melakukan kreasi menu makanan sesuai pangan lokal yang ada disekitarnya tanpa menunggu bantuan sumber menu makanan dari luar. Diketahui bahwa masyarakat Kampar sebagian besar petani sawah seperti padi, jagung, tambak seperti ikan nila, patin, peternak ayam, pekebun pisang, papaya, jeruk, kelapa, dan lainnya, serta sebagian ada yang memiliki industri tahu, sehingga bisa diperoleh dari pangan dan olahan pangan setempat dengan variasi menu yang bisa beraneka ragam dan harga lebih terjangkau. Adanya ketersediaan pangan dan olahan lokal bisa menjadi suatu peluang untuk memunculkan kreativitas yang bernilai ekonomi dengan penyediaan MP-ASI dan PMT balita yang hiegenis, bernilai gizi baik dengan kemasan yang menarik.

Oleh karena itu, tak jarang dijumpai masih banyak ibu balita yang hanya memberikan makanan berupa bubur beras saja, yang diberikan berupa nasi yang hanya ditambah kuah sayur atau kuah ikan, serta masih rendahnya pemahaman ibu balita tentang MP-ASI dan PMT yang padat zat gizi. Padahal, seorang kader seharusnya merupakan penyuluh yang handal karena merupakan promotor atau penggerak kesehatan yang direkrut dari, oleh dan untuk masyarakat, yang bertugas membantu kelancaran pelayanan kesehatan. Sehingga seorang kader posyandu harus mau bekerja secara sukarela dan ikhlas, mau dan sanggup melaksanakan kegiatan posyandu, serta mau dan sanggup menggerakkan masyarakat untuk melaksanakan dan mengikuti kegiatan posyandu.

Oleh karena itu dipandang perlu bagi Tim Pengabdi Dosen Fakultas Ilmu Kesehatan untuk melakukan pengabdian kepada masyarakat dengan mengambil judul "Pemenuhan Makanan Balita" di Desa Ranah Singkuang Wilayah Kerja Puskesmas Kampar Kabupaten Kampar".

\section{METODE}

Metode yang digunakan dalam pengabdian masyarakat ini adalah dengan melakukan a). Penyuluhan pada ibu yang mempunyai balita guna meningkatkan pemahaman ibu terhadap pemenuhan makanan tambahan, penyediaan, pengolahan PMT balita. b) Pelatihan membuat PMT, yang bertujuan untuk meningkatkan keterampilam ibu dalam membuat PMT. c) konsultasi PMT, yang bertujuan meningkatkan pemahaman ibu dan melakukan tanya jawab seputar PMT.

\section{HASIL DAN PEMBAHASAN}

Hasil pelaksanaan kegiatan PPM secara garis besar dapat dilihat berdasarkan komponen sebagai berikut:

1. Penyuluhan Makanan Tambahan Pada Balita

Ada peningkatan $75 \%$ pengetahuan dari peserta tentang pemenuhan makanan tambahan di Desa Ranah Singkuang sehingga peserta bisa mengetahui penyediaan, pengolahan PMT balita. Penyuluhan ini menggunakan metode ceramah tanya jawab untuk mendukung kemampuan peserta dalam menguasai materi yang disampaikan. Penyuluhan ini dapat meningkatkan pengetahuan Ibu dalam penyediaan dan pengolahan makanan tambahan. 
Materi penyuluhan berupa: (a) pengetahuan tentang pemenuhan makanan tambahan, (b) penyediaan, (c) waktu pemberian, (d) pengolahan pemenuhan makanan tambahan dari bahan yang sederhana. Semua materi tersebut dapat disampaikan oleh tim pengabdi dengan waktu yang terbatas.

Pemberian Makanan Tambahan (PMT) adalah kegiatan pemberian makanan kepada balita dalam bentuk kudapan yang aman dan bermutu beserta kegiatan pendukung lainnya dengan memperhatikan aspek mutu dan keamanan pangan. Serta mengandung nilai gizi yang sesuai dengan kebutuhan sasaran.

Pemberian Makanan Tambahan (PMT) ada dua macam yaitu Pemberian Makanan Tambahan (PMT) pemulihan dan Pemberian Makanan Tambahan (PMT) penyuluhan. Memiliki tujuan yang sama yaitu untuk memenuhi kebutuhan zat gizi yang dibutuhkan oleh balita.

PMT pemulihan dimaksudkan untuk memenuhi kebutuhan gizi balita sekaligus sebagai pembelajaran bagi ibu dari balita sasaran. PMT pemulihan diberikan dalam bentuk makanan atau bahan makanan lokal. Hanya dikonsumsi oleh balita gizi buruk dan sebagai tambahan makanan sehari-hari bukan sebagai makanan pengganti makanan utama.

Makanan tambahan pemulihan diutamakan berbasis bahan makanan lokal. Jika bahan lokal terbatas dapat digunakan makanan pabrikan yang tersedia di wilayah setempat dengan memperhatikan kemasan, label dan masa kadaluarsa untuk keamanan pangan. Diuatamakan berupa sumber protein hewani dan nabati serta sumber vitamin dan mineral terutama berasaal dari sayur dan buah. PMT pemulihan ini diberikan sekali dalam satu hari selama 90 hari berturut-turut atau 3 bulan.

Makanan tambahan pemulihan dapat berupa pabrikan dan lokal. PMT pemulihan pabrikan merupakan yaitu makanan pendamping ASI dalam bentuk biskuit yang mengandung 10 vitamin dan 7 mineral. Biskuit hanya untuk anak usia $12-24$ bulan, dengan nilai gizi : energi total $180 \mathrm{kkal}$, lemak 6 gram, protein 3 gr. Jumlah persajinya mengandung 29 gr karbohidrat total, 2 gr serat pangan, 8 gr gula dan $120 \mathrm{mg}$ natrium.

Sedangkan PMT pemulihan berbasis bahan makanan lokal ada dua jenis yanitu berupa Makanan Pendamping Air Susu Ibu (MP-ASI) untuk bayi dan anak usia 6 - 23 bulan ) dan makanan tambahan untuk pemulihan anak balita 24-59 bulan berupa makanan keluarga.

2. Pelatihan membuat makanan tambahan

Ketercapaian tujuan pelatihan dapat dikatakan baik (80\%). Ada peningkatan pengetahuan dari peserta tentang pemenuhan makanan tambahan, serta keterampilan dalam pembuatan makanan tambahan yang baik dan benar. Pelatihan membuat makanan tambahan pada ibu yang mempunyai balita di Desa Ranah Singkuang Kecamatan Kampar Kabupaten Kampar diharapkan dapat terwujud dengan baik melalui pemberian makanan tambahan di Desa Ranah Singkuang guna menunjang pelaksanaan pememuhan makanan tambahan.

Sejalan dengan yang dikemukakan oleh Adisasmito (2012), bahwa status gizi dipengaruhi oleh 2 penyebab, yaitu penyebab langsung dan tidak langsung. Penyebab langsung 40 adalah asupan makan dan penyakit infeksi yang diderita anak. Secara tidak langsung dipengaruhi oleh pola asuh, faktor ekonomi, budaya, pengetahuan dan pendidikan. Pengetahuan mengenai penyusunan menu guna memenuhi kebutuhan asupan makan bayi sangat penting, karena akan berdampak pada status gizi anak. Pemilihan jenis bahan makanan sedemikian rupa untuk mendapatkan menu terbaik sekaligus mengupayakan variasi menu agar anak tidak merasa bosan sehingga, mempengaruhi tingkat konsumsi. Tingkat konsumsi makan akan berdampak pada status gizi anak.

Lonika (2011) menjelaskan bahwa status gizi balita dapat dipengaruhi oleh tingkat pendapatan keluarga dimana akan mempengaruhi pola konsumsi suatu keluarga. Semakin tinggi pendapatan keluarga, maka kemampuan membeli makanan yang mengandung gizi tinggi akan meningkat, begitu juga sebaliknya. Keluarga yang berpenghasilan kurang tidak mampu untuk membeli makanan yang mengandung gizi.

3. Konsultasi PMT

Pada sesi konsultasi ada beberapa pertanyaan yang diajukan peserta, antara lain: apakah ada pantangan makan bagi balita, jenis dan bahan yang dapat dijadikan makanan bagi balita, dan lain sebagainya. Para peserta cukup senang dan antusias dengan adanya program PKM ini. 
PKM ini dapat memberikan kontribusi dalam peningkatan pengetahuan dan keterampilan Ibu dalam memberikan makanan tambahan di Desa Ranah Singkuang. Dengan meningkatnya pengetahuan dan keterampilan Ibu dalam mengolah dan menyajikan makanan tambahan pada balita, maka akan meningkatkan kualitas pertumbuhan dan perkembangan anak secara optimal dan maksimal.

\section{SIMPULAN}

Simpulan dalam PKM pemenuhan makanan balita ini adalah :

1. Pelatihan Pemenuhan Makanan Tambahan di Desa Ranah Singkuang Kecamatan Kampar Kabupaten Kampar dapat meningkatkan pengetahuan tentang pengertian MP ASI dan pemenuhan makanan tambahan, penyediaan, waktu pemberian, pengolahan MP ASI dan pemenuhan makanan tambahan dari bahan yang sederhana.

2. Peningkatan pengetahuan dan keterampilan bagi peserta pelatihan tentang pemenuhan makanan tambahan dilakukan dengan metode ceramah dan demonstrasi.

3. Penurunan status gizi kurang pada balita di Desa Ranah Singkuang diharapkan dapat terwujud dengan baik dengan adanya penyuluhan dan pemberian makanan tambahan.

\section{SARAN}

Saran yang dapat diberikan dalam PKM pemenuhan makanan pada balita ini adalah : Perlunya monitoring, evaluasi dan pendampingan secara rutin pasca pelaksanaan Program PKM Pemenuhan Makanan Tambahan di Desa Ranah Singkuang sehingga program PKM ini dapat berkelanjutan dan memberikan manfaat kepada balita di Desa Ranah Singkuang sehingga masyarakat di Desa Ranah Singkuang memiliki pengetahuan, kesadaran dan pemahaman tentang manfaat pentingnya pemenuhan makanan tambahan bagi balita secara benar dan sehat.

\section{UCAPAN TERIMA KASIH}

Kegiatan Pengabdian Kepada Masyarakat berupa penyuluhan dan pelatihan tentang MP ASi dan PMT di Desa Ranah Singkuang ini dapat terlaksana atas fasilitasi Pengabdian Kepada Masyarakat (PKM) yang dibiayai oleh Internal Fakultas Kesehatan Universitas Pahlawan Tuanku Tambusai. Oleh karena itu, tim PKM menyampaikan ucapan terimakasih kepada semua pihak yang telah membantu pelaksanaan kegiatan ini yaitu: Dekan Fakultas Kesehatan Universitas Pahlawan Tuanku Tambusai; Ketua LPPM, Kepala Desa dan Bidan Desa Ranah Singkuang, dosendosen dan mahasiswa Universitas Pahlawan Tuanku Tambusai.

\section{DAFTAR PUSTAKA}

Adisasmito. 2012. Sistem Kesehatan. PT Gramedia Grafindo Persada. Jakarta

Eko Putro Sandjojo,Taufik Majid.(2017). Buku Saku Desa dalam Penanganan Stunting. Direktur Jenderal Pembangunan dan Pemberdayaan Masyarakat Desa.

Tim Nasional Percepatan Penanggulangan Kemiskinan.(2017). 100 Kabupaten/Kota Prioritas Untuk Intervensi Anak Kerdil (STUNTING).

Pusat Data dan Informasi, kementrian Kesehatan RI. (2018). Situasi Balita Pendek (Stunting) di Indonesia.

Farida. (2015). Register Kohort Balita Desa Balong Tani Kecamatan Jabon.

UNICEF. Paket Konseling (2014). Pemberian Makan Bayi dan Anak.

Kepala Badan Pengawas Obat dan Makanan (2007). B. Acuan Label Gizi Produk Pangan.

Kemenkes RI (2014). Modul Pelatihan Konseling : Pemberian Makan Bayi Dan Anak.

Lonika. 2011. Faktor - Faktor Yang Berpengaruh Terhadap Status Gizi Balita Di Kecamatan Kuranji Kota Padang. Skripsi. Universitas Andalas. Medan.

Silawati A, dkk (2013). Pemberian Makanan Pada Bayi Dan Anak (PMBA) Dalam Situasi Bencana. 